\title{
The State and Needs of the Development of Water Supply and Sewerage Infrastructure in The Radzyń District
}

\author{
Monika Bogusz' ${ }^{1}$ Michał Marzec ${ }^{2 *}$, Arkadiusz Malik², Krzysztof Jóźwiakowski \\ 1 Student Science Association of Water and Wastewater Management, University of Life Sciences in Lublin, \\ Akademicka 13, 20-950 Lublin, Poland \\ 2 Department of Environmental Engineering and Geodesy, University of Life Sciences in Lublin, Leszczyńskiego \\ 7, 20-069 Lublin, Poland \\ * Corresponding author's e-mail: michal.marzec@up.lublin.pl
}

\begin{abstract}
The paper presents the current state of water supply and sewerage infrastructure and the need for its expanding in Radzyń district. The district is located in the northern part of Lublin Voivodeship in Poland. The following communes belong to Radzyń district: the municipal commune of Radzyń Podlaski and 7 rural communes: Borki, Czemierniki, Kąkolewnica, Komarówka Podlaska, Radzyń Podlaski, Ulan-Majorat, Wohyń. The data show that the water supply network in Radzyń district is well developed. The most significant percentage of the population using the water supply network has the rural commune of Radzyń Podlaski - 99.9\%, while the smallest, commune Komarówka Podlaska - 54.5\%. The survey showed that there was a very large disproportion between the development of the sewerage and water supply systems. The largest percentage of the population using the sewerage network has the municipal commune of Radzyń Podlaski - 99.7\%. The smallest percentage of users of collective sewage disposal systems was recorded in the rural commune of Radzyń Podlaski (7.2\%). The commune of UlanMajorat does not have a sewerage system. The survey conducted in 2016 shows that 8 collective wastewater treatment plants operated in Radzyń district at that time. The total capacity of the treatment plants is over $5,300 \mathrm{~m}^{3} / \mathrm{d}$. In 2016, Radzyń district had about 1,000 household wastewater treatment plants. The presented data show that the condition of the sanitary infrastructure in rural communes of Radzyn district is unsatisfactory and requires the investment activities mainly aimed at expanding collective sewage disposal and treatment systems as well as developing a network of household wastewater treatment plants.
\end{abstract}

Keywords: water supply network, sewerage network, collective wastewater treatment plants, household wastewater treatment plants.

\section{INTRODUCTION}

One of the most important factors determining the socio-economic development of a given area is the state of its sanitation infrastructure, i.e. its water supply and wastewater disposal and treatment systems. In Poland, recent years have witnessed increased investment in the construction and modernization of water supply and sewerage systems [Pawełek 2016; Pawełek and Bugajski 2017]. This has been an effect of the socio-economic changes taking place in Poland, an increase in ecological awareness, greater interest in improving the state of the environment, continuous technological progress and better access to new technological solutions.

Water and wastewater management in Poland still does not keep up with the user's needs - the sewerage network is not being expanded fast enough. The disproportion between the length of the water supply network and the sewerage network indicates that the latter is subsidiary to the former, and that its expansion is strictly dependent on access to a water supply system. Other important factors that hinder the expansion of the sewerage network is its greater technical complexity and the capital-intensity of investment in its construction [Micek et al. 2018; CSO_2018]. 
There are large differences in sewerage network coverage between urban and rural areas. Sewerage systems in large urban agglomerations are expanded at a much faster rate than those located in rural or urban-rural communes. It can be assumed that in cities, the expansion of sewerage systems keeps pace with the expansion of water supply systems. According to 2017 data, $90.2 \%$ of the urban population had access to sewerage systems compared to the mere $40.8 \%$ of the rural population [CSO 2018].

The goal of this study was to assess the status of sanitation infrastructure and the need for the expansion of the water supply and sewerage networks in the Radzyń district. We used available statistical data and the results of a 2016 survey conducted in eight communes of the Radzyn district by the Department of Environmental Engineering and Geodesy of the University of Life Sciences in Lublin. The data collected in the survey concerned, among others, the lengths of the active water supply and sewerage networks, the number of inhabitants connected to each of these networks, the number of centralized wastewater treatment plants with a capacity exceeding $5 \mathrm{~m}^{3} / \mathrm{d}$, and the number of on-site domestic wastewater treatment plants.

\section{THE CHARACTERISTICS OF THE RADZYŃ PODLASKI DISTRICT}

The Radzyń district is one of the 24 districts of the Lubelskie Voivodship. It is located in the northern part of the voivodship (Figure 1). The district covers an area of $965.1 \mathrm{~km}^{2}$, which constitutes $3.84 \%$ of the area of the voivodship. The district has about 59,640 inhabitants, i.e. $2.85 \%$ of the population of the voivodship (as of Dec. 31, 2017) [Statistical Office in Lublin 2018]. To the north-east, the Radzyń district borders the Biała Podlaska district, to the east - the Parczew district, to the south - the Lubartów district, and to the west the Łuków district. The capital of the Radzyn district is the town of Radzyń Podlaski. The Radzyń Podlaski district comprises the following communes: the Radzyń Podlaski municipal commune and 7 rural communes: Borki, Czemierniki, Kąkolewnica, Komarówka Podlaska, Radzyń Podlaski, Ulan-Majorat, and Wohyń (Figure 2).

The largest of these communes is Wohyn, which spans an area of nearly $180 \mathrm{~km}^{2}$, and the smallest - the municipality of Radzyń Podlaski - $19.3 \mathrm{~km}^{2}$ [Board of the Radzyń District 2019]. The municipality of Radzyń Podlaski is also the most populated commune in the district. It has over 15,800 inhabitants, with a population density of ca. 819 people $/ \mathrm{km}^{2}$. The commune with the smallest population is Komarówka Podlaska, which has ca. 4,300 inhabitants, and a population density of about 31 people $/ \mathrm{km}^{2}$ (Table 1 ).

The western part of the Radzyń district (the communes of Borki, Czemierniki, and Ulan-Majorat, the town of Radzyń Podlaski and part of the municipality of Radzyń Podlaski and the commune of Kąkolewnica) extends over the area of three geographical regions of the South Podlasie Lowland macroregion: the Łuków Plains, the Lubartów Upland, and the Wieprz

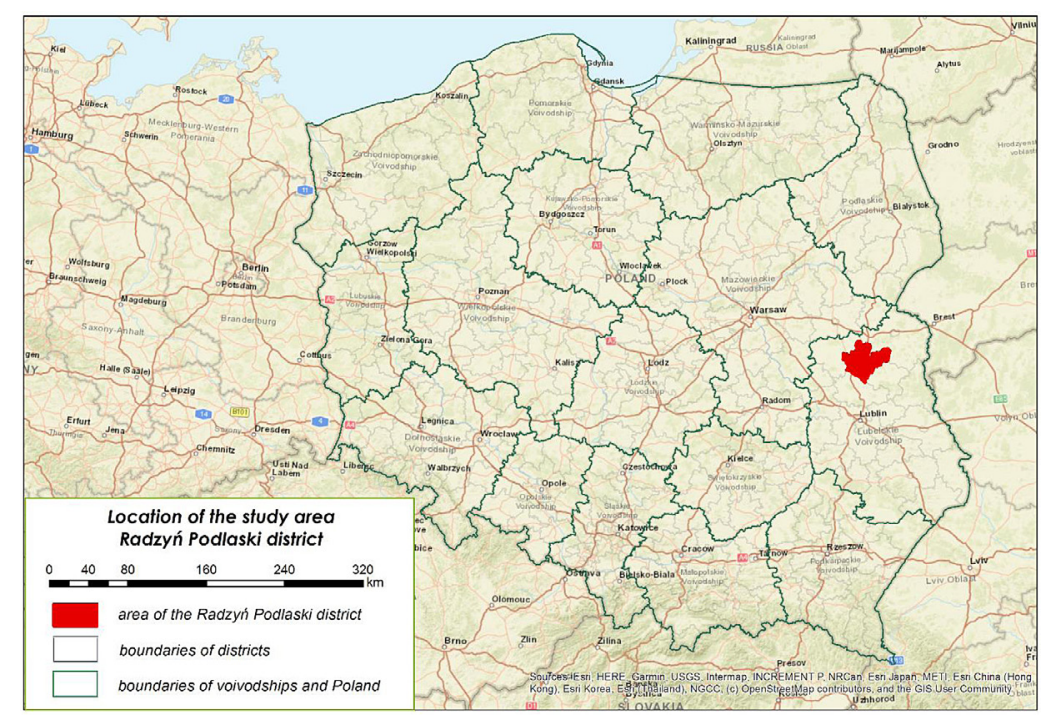

Fig. 1. Geographical location of Radzyń district in Poland 


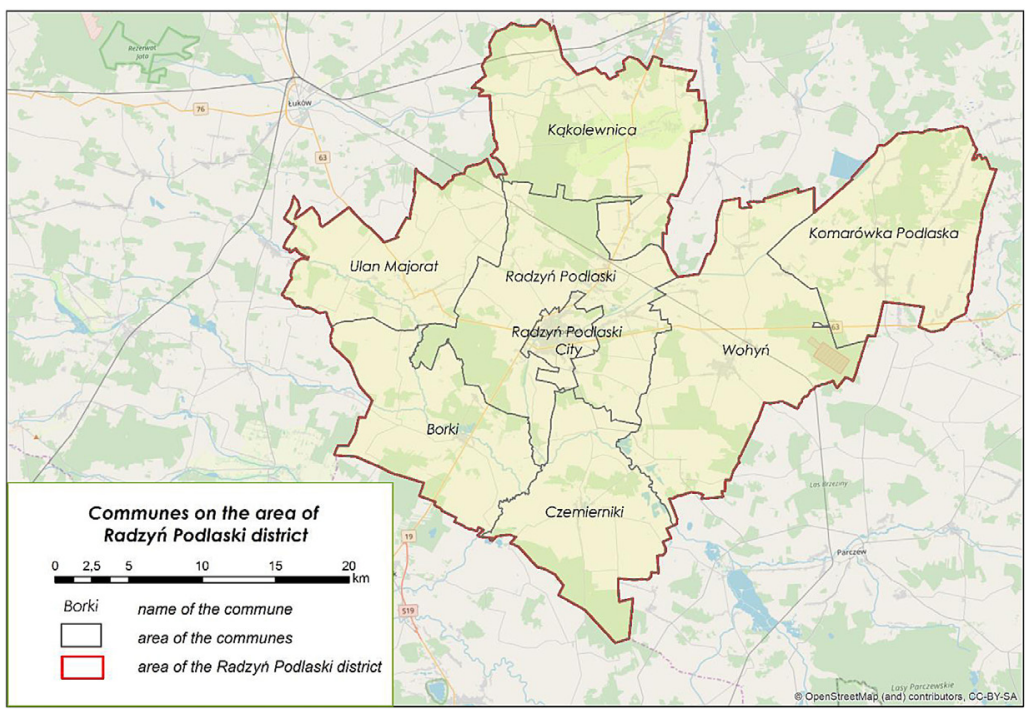

Fig. 2. The communes of Radzyń district

River Glacial Valley. The eastern part of the Radzyń district (the communes of Wohyń and Komarówka Podlaska) is part of the Western Polesie macroregion, and the mesoregions of the Łomazy Depression and the Parczew Plains [District Office in Radzyń Podlaski 2015a; Kondracki 2002].

The Radzyń district is located in the Eastern Lesser Poland climatic region and the Chełm-Podlasie climatic subregion. The average annual air temperature in the Radzyń district for the years $1951-1980$ was $7.2-7.3{ }^{\circ} \mathrm{C}$; the average temperature in January was $-4.6^{\circ} \mathrm{C}$, and the average temperature in July was $18{ }^{\circ} \mathrm{C}$. The average annual precipitation in the years 1975-1980 was 530-545 mm [District Office in Radzyń Podlaski 2015a].

The river network in the Radzyń district is extensive, with eight rivers flowing through this area: Białka, Bystrzyca, the Wieprz-Krzna Canal, Krzna, Piwonia, Samica, Stanówka, and
Tyśmienica. The groundwaters of the district are associated with Quaternary, Tertiary, and Cretaceous deposits. The majority of the district lies within the area of three Major Groundwater Reservoirs: GZWP 215 - the Warsaw Subbasin, GZWP 406 - the Lublin Basin (Niecka Lubelska), and GZWP 224 - the Podlasie Subreservoir [District Office in Radzyń Podlaski 2015b]. The quality of water in the rivers of the district is monitored and tested by the Provincial Inspectorate for Environmental Protection in Lublin at the measurement and monitoring stations of the Regional Monitoring Network. These tests are performed for the rivers: Krzna Południowa, Tyśmienica, Białka, Piwonia and Bystrzyca Północna. The Radzyń Podlaski district has three groundwater monitoring stations, which are part of the national network: in Biała near Radzyń, in Kuraszew (commune of Wohyń) and in Komarówka Podlaska. The station in Biała monitors confined

Table 1. Characteristics of the communes of Radzyń district [Statistical Office in Lublin 2018; http://www.polskawliczbach.pl/powiat_radzynski]

\begin{tabular}{|l|c|c|c|c|c|}
\hline Name of commune & $\begin{array}{c}\text { Area } \\
{\left[\mathrm{km}^{2}\right]}\end{array}$ & $\begin{array}{c}\text { Proportion of district } \\
\text { area occupied by } \\
\text { the commune [\%] }\end{array}$ & Population & $\begin{array}{c}\text { Proportion of district } \\
\text { population occupied by the } \\
\text { commune [\%] }\end{array}$ & $\begin{array}{c}\text { Population density } \\
{[\text { people/km²] }}\end{array}$ \\
\hline $\begin{array}{l}\text { Municipal commune } \\
\text { of Radzyń Podlaski }\end{array}$ & 19.3 & 2.0 & 15808 & 26.5 & 819 \\
\hline Borki & 111.8 & 11.6 & 6030 & 10.1 & 54 \\
\hline Czemierniki & 107.5 & 11.1 & 4394 & 7.4 & 41 \\
\hline Kąkolewnica & 147.5 & 15.3 & 8169 & 13.7 & 56 \\
\hline $\begin{array}{l}\text { Komarówka } \\
\text { Podlaska }\end{array}$ & 138 & 14.3 & 4295 & 7.2 & 31 \\
\hline Radzyń Podlaski & 155 & 16.1 & 8099 & 13.6 & 52 \\
\hline Ulan-Majorat & 107.8 & 11.1 & 6030 & 10.1 & 56 \\
\hline Wohyń & 178.2 & 18.5 & 6775 & 11.4 & 38 \\
\hline
\end{tabular}


deep-water from Quaternary aquifers, the station in Komarówka assesses shallow groundwater, and the station in Kuraszew controls groundwater and confined deep-water bounded by Jurassic and Cretaceous deposits. Waters of the rivers covered by the assessment are assigned to the water quality class III as far as the general classification is concerned. In terms of their hydrobiological, bacteriological, hydromorphological and physicochemical status, they meet the requirements set for water quality class II. The general status of the rivers is moderate [District Office in Radzyń Podlaski 2015a].

Legally protected areas in the Radzyn district occupy ca. 839.10 ha, i.e. $0.9 \%$ of the area. They include nature reserves ( $15.5 \mathrm{ha})$, protected landscape areas (650 ha), and ecological sites (173.6 ha). The only area with a conservation status is the "Czapliniec" Fauna Reserve, located in a forest complex near the village of Sitno on the border of the Borki commune and the Radzyń Podlaski municipality. The district boasts fifty four natural monuments [District Office in Radzyń Podlaski 2015b].

The Radzyń district is a typically agricultural area. Agricultural land occupies $73.4 \%$ of the district's total area, with arable land alone taking up $51.8 \%$ of that area. $21.2 \%$ of the district's area is covered by forests [District Office in Radzyń Podlaski 2015b].

The district has a relatively favourable settlement pattern. It consists of one municipal commune and seven rural communes with a total of 128 villages. The district's settlements have either a nucleated or a dispersed form. The dominant development form is rural single-family residential development. There are also hamlets and villages where single solitary dwellings predominate. The least numerous group are villages with dispersed and irregular development patterns and villages with concentrations of single farmsteads lying outside the main village area. The commune with the smallest number of villages is the commune of Czemierniki. The largest number of rural settlements (24) are located in the municipal commune of Radzyń Podlaski [District Office in Radzyń Podlaski 2015a].

\section{RESULTS AND DISCUSION}

The state of the sanitation infrastructure in the Radzyń district was assessed on the basis of the results of a survey carried out in the communes of the district in 2016. The information obtained in the survey regarded the lengths of the water supply and sewerage networks in each commune, the number of inhabitants connected to each of these networks, the number and capacity of centralized wastewater treatment plants with a capacity exceeding $5 \mathrm{~m}^{3} / \mathrm{d}$ and the number of on-site domestic wastewater treatment plants. The survey data was supplemented with official statistics.

The state of the water supply infrastructure in the Radzyń district turned out to be satisfactory. The total length of the water supply network in the district in 2016 was over $880 \mathrm{~km}$, which represented about $4.2 \%$ of the total length of the water supply network in the Lubelskie Voivodship [Statistical Office in Lublin 2017b]. The Wohyń commune had the most extensive water supply network of over $177 \mathrm{~km}$ (Figure 3). The municipality of Radzyń Podlaski and the commune of Komarówka Podlaska had the shortest water supply networks - just over $40 \mathrm{~km}$ each. The average density of the water supply network in the

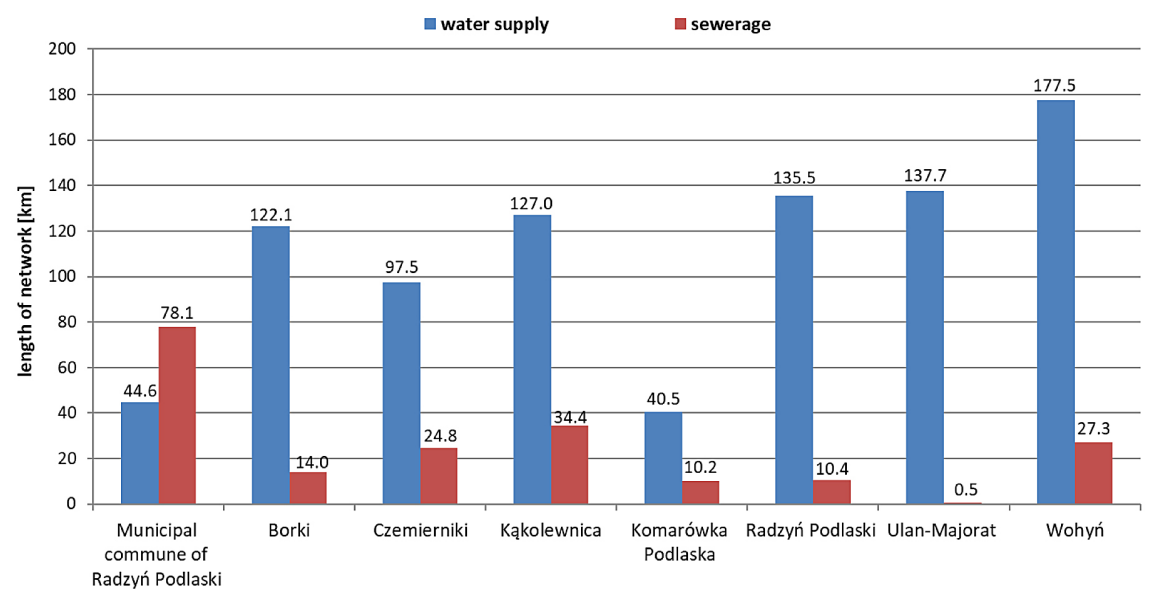

Fig. 3. The length of the water supply and sewerage network in Radzyń district in 2016 
Radzyń district in 2016 was $91.4 \mathrm{~km} / 100 \mathrm{~km}^{2}$, which was higher than the average density of the water supply network for the Lublin province $\left(84.1 \mathrm{~km} / 100 \mathrm{~km}^{2}\right)$ [Statistical Office in Lublin 2017b]. There was a clear difference, however, between the municipal commune of Radzyń Podlaski and the rural communes. While the density index for the municipality was $231 \mathrm{~km} / 100 \mathrm{~km}^{2}$, the indexes for the other communities did not exceed $100 \mathrm{~km} / 100 \mathrm{~km}^{2}$, with the index for the Komarówka Podlaska commune being as low as $30 \mathrm{~km} / 100 \mathrm{~km}^{2}$. However, it should be noted that the length of the network is not the most reliable parameter on which to assess a water supply system. Network length is a corollary of the degree of dispersion of settlements in a given area and is rather a measure of local government spending on investments associated with supplying water to the local population. The main task of a water supply system is to provide good quality water to the largest possible number of recipients in a given area, and how well this task is executed does not always depend directly on the length of the network. A more useful assessment criterion is the percent of inhabitants serviced by the system. With respect to this criterion, the situation in the Radzyń district is quite clear.

The surveys show that in 2016, approximately $90 \%$ of the district's population were connected to the water supply system. Among the analysed communes, the municipal commune of Radzyń Podlaski had the largest water supply coverage $-99.9 \%$, and the commune of Komarówka Podlaska had the smallest coverage $-54.5 \%$ (Figure 4). It is worth mentioning that the water supply networks in the investigated communes had an almost identical length, which indicates that the length of a network itself is not decisive for effective supply of water to users. What does determine it is the spatial distribution pattern and the settlement concentration index. When the length of the water supply network was juxtaposed against the number of inhabitants connected to it, it turned out that the municipal commune of Radzyń Podlaski was the only one with a reasonable length-to-user ratio of $2.8 \mathrm{~m}$ per user. In the commune of Komarówka Podlaska, this ratio exceeded $17 \mathrm{~m}$ per user. In the communes of Borki, Czemierniki, Ulan-Majorat and Wohyń, the situation was even less favorable. While the water supply coverage in those communes was relatively high (over 90\%), it required as many as 22 to $28 \mathrm{~m}$ of water supply pipes_to connect each of the users to the water supply, which was associated with significantly higher investment costs.

According to the survey data, the total length of the sewerage network in the Radzyń district in 2016 was $200 \mathrm{~km}$, which was about $23 \%$ of the length of the water supply network. The commune with the longest sewerage network was the municipality of Radzyń Podlaski: despite the high concentration of population, the length of the active public sewerage network was $78.1 \mathrm{~km}$ (Figure 3). Almost all residents of the commune had access to the sewerage network in 2016. The sewerage networks in the remaining communes were not longer than $35 \mathrm{~km}$, which, given the more dispersed settlement pattern of those places, meant that only a small percentage of the inhabitants of those communes $(24.8-43 \%)$ were connected to the sewerage system. Much lower figures were found for the rural communes of Radzyń Podlaski and Ulan-Majorat - 7.2\% and $0.4 \%$, respectively. The average sewerage

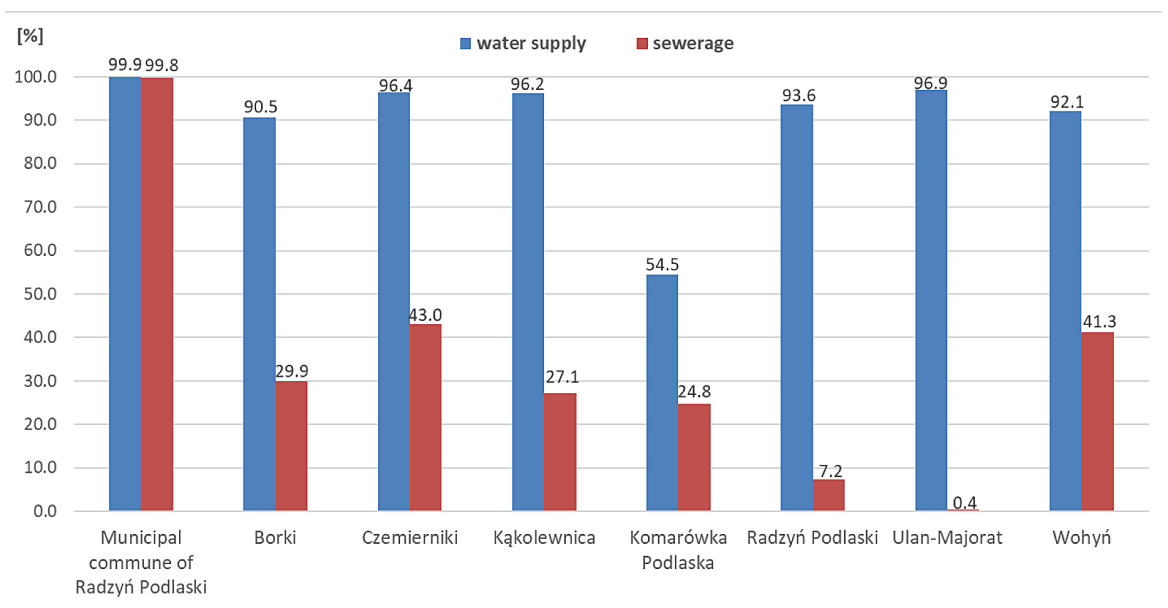

Fig. 4. Percentage of residents of Radzyń district with access to the water supply and sewerage network in 2016 
network coverage for the district, expressed as the percent of inhabitants connected to the mains sewerage network was around $35 \%$ in 2016 . To compare, the sewerage network in the Lublin province had a coverage of around $57 \%$ in the same year [Statistical Office in Lublin 2017a]. The average density of the sewerage network in the Radzyń district was $20.7 \mathrm{~km} / 100 \mathrm{~km}^{2}$ in 2016 . In this respect, the situation in the district was less favorable than in the entire Lublin province, where the ratio was $25.7 \mathrm{~km} / 100 \mathrm{~km}^{2}$. In the municipal commune of Radzyń Podlaski, the density of the sewerage network was $404 \mathrm{~km} / 100 \mathrm{~km}^{2}$. To compare, the density of the sewerage networks in the other communes of the district did not exceed $23 \mathrm{~km} / 100 \mathrm{~km}^{2}$ and in the commune of Ulan-Majorat it was only $0.46 \mathrm{~km} / 100 \mathrm{~km}^{2}$. In the Radzyn district, the mean length of the sewerage network per connected inhabitant was $7.5 \mathrm{~m}$; it ranged from $4.9 \mathrm{~m}$ per inhabitant for the municipality of Radzyń Podlaski to 22.7 m per inhabitant for the commune of Ulan-Majorat. According to the guidelines of the National Programme for Municipal Wastewater Treatment (KPOŚK), the length of the sewerage network per inhabitant should not be greater than $8 \mathrm{~m}$ [Heidrich and Stańko 2008; AKPOŚK 2017]. The relatively large length of the sewerage network per inhabitant in the municipality of Radzyń Podlaski may be associated with the fact that the town has a separate sewer system that separates sewage from stormwater, and the survey probably provides data on the summary length of the sewage and runoff collectors. It should be noted here, that the lengths of the sewerage systems per user are more favorable than in the case of the water supply system. These data show that investments in expanding the water supply systems in the communes of the Radzyń district are treated as a priority and money is spent on their construction despite the high investment costs resulting from the large dispersion of households. Investment tasks related to the extension of the sewerage network are not viewed as being mandatory. They are implemented when local governments have the necessary financial resources. Also, the sewerage network is extended in the first place in those areas where the investment is guaranteed to achieve an adequate level of economic efficiency. Moreover, in areas with unfavorable settlement patterns, sewage can be treated using alternative, more economically viable means.
According to the results of the survey, in 2016, the Radzyń district had eight centralized biological wastewater treatment plants with a throughput of over $5 \mathrm{~m}^{3} / \mathrm{d}$ each. Seven of these facilities were located in the rural communes of the district - three of them in the Wohyń commune. The capacity of these wastewater treatment plants was between 55 and $400 \mathrm{~m}^{3} / \mathrm{d}$ (Table 2).

The district's largest centralized wastewater treatment plant is located in the municipal commune of Radzyń Podlaski. It treats sewage from the town and the neighbouring villages. The facility has a throughput of $3,900 \mathrm{~m}^{3} / \mathrm{d}$.

Mains sewerage systems are the best solution for the disposal and treatment of wastewater, however, the possibility of constructing such systems may be limited by many factors, mainly technical and economic. These factors are related to the topography of the terrain, soil and water conditions and the settlement pattern, which is why they are of particular importance in rural areas [Micek et al. 2018]. In situations where there are no reasonable grounds for building a mains sewerage network, sanitation programs need to adopt offmains sewage treatment solutions, including the construction of domestic wastewater treatment plants. Facilities of this type can serve up to 50 inhabitants [PN-EN 12566-3: 2016-10]. Domestic wastewater treatment plants are also a good alternative to sealed tanks (cesspools), which are now the most common element of sanitation infrastructure in areas with a dispersed development pattern [CSO 2018]. Relatively high costs of maintaining cesspools and potential threats to the environment [Karolinczak et al. 2015; Błażejewski and Nawrot 2009; Nowak 2012] prompt individual

Table 2. Collective wastewater treatment plants with a capacity of more than $5 \mathrm{~m}^{3} / \mathrm{d}$ in the communes of Radzyń district

\begin{tabular}{|l|c|}
\hline \multicolumn{1}{|c|}{ Name of treatment plant (commune) } & $\begin{array}{c}\text { Capacity } \\
{\left[\mathrm{m}^{3} / \mathrm{d}\right]}\end{array}$ \\
\hline $\begin{array}{l}\text { Radzyń Podlaski (Municipal commune of } \\
\text { Radzyń Podlaski) }\end{array}$ & 3900 \\
\hline Borki (Borki) & 55 \\
\hline Czemierniki (Czemierniki) & 400 \\
\hline Kąkolewnica (Kąkolewnica) & 195 \\
\hline $\begin{array}{l}\text { Komarówka Podlaska (Komarówka } \\
\text { Podlaska) }\end{array}$ & 150 \\
\hline Wohyń (Wohyń) & 375 \\
\hline Suchowola (Wohyń) & 150 \\
\hline Bezwola (Wohyń) & 80 \\
\hline
\end{tabular}


investors and local governments to turn their attention to on-site wastewater treatment systems. The most commonly used domestic wastewater treatment solutions include: a septic tank with a drainfield, a septic tank with a sand filter, a mobile container wastewater treatment plant with activated sludge, a container sewage treatment plant with a biological filter bed, and a constructed wetland [Jawecki et al. 2015; Pawełek and Bugajski 2017]. To select the right technological system for the treatment of domestic wastewater one has to consider numerous technological, environmental and economic factors, as well as the specific conditions that have an impact on sewage management in a given area [Karolinczak et al. 2015; Mucha and Mikosz 2009]. These include, among others: low water consumption per capita, highly variable wastewater inflow rates and pollutant loading rates, improper use of the sewerage piping system, low temperature of sewage in winter, low quality of maintenance procedures, and lower reliability of sewage treatment plants [Mucha and Mikosz 2009 ].

The analysis of the survey data shows that in the Radzyń district, the segment of off-mains wastewater treatment systems is gaining in importance. In 2016, nearly 1,000 domestic wastewater treatment plants based on various technological solutions were registered in the Radzyń district. Most of them (448) were located in the rural commune of Radzyń Podlaski. Also, large numbers of households were connected to domestic wastewater treatment plants in the communes of Borki 223 and Ulan-Majorat - 200 (Figure 5). In the remaining communes, the network of domestic wastewater treatment plants was relatively small, with less than 50 facilities each. A large percent of the domestic wastewater treatment systems in the district were conventional biological wastewater treatment plants. Beside those, there were seminatural wastewater treatment systems, among others, constructed wetlands. This should be viewed as a favorable trend, taking into account the fact that in the Lublin province, the most common technological solution used for the treatment of domestic sewage are systems with a drainfield [Jóźwiakowski et al. 2014]. In the rural commune of Radzyń Podlaski, most of the treatment facilities were plants with a low-load activated sludge stage [Marzec and Jóźwiakowski 2007; 2010]. For many years, this commune had been implementing a sanitation programme aimed at building a network of domestic wastewater treatment plants which would neutralize the negative effects of the very dispersed development pattern. This explains the small size of the mains sewerage network in this commune. However, monitoring data for the domestic systems in the rural commune of Radzyń Podlaski indicate that there are many problems associated with their use that may pose a threat to the natural environment. Despite the high level of technological advancement of the solutions used, they do not properly fulfil their role as regards the protection of the soil and water environment [Marzec and Jóźwiakowski 2007; Marzec and Jóźwiakowski 2010; Marzec 2018]. This corroborates the claim that domestic systems should be used in rural areas as an alternative to mains sewerage networks and septic tanks, but only when certain conditions are met. The most important of those is a change of approach to domestic treatment systems, in particular, users should be made aware of the fact that these systems are not maintenance-free and require periodic performance checks. If such facilities are built as part of a communal sanitation programme, local governments should provide adequate supervision of their construction and

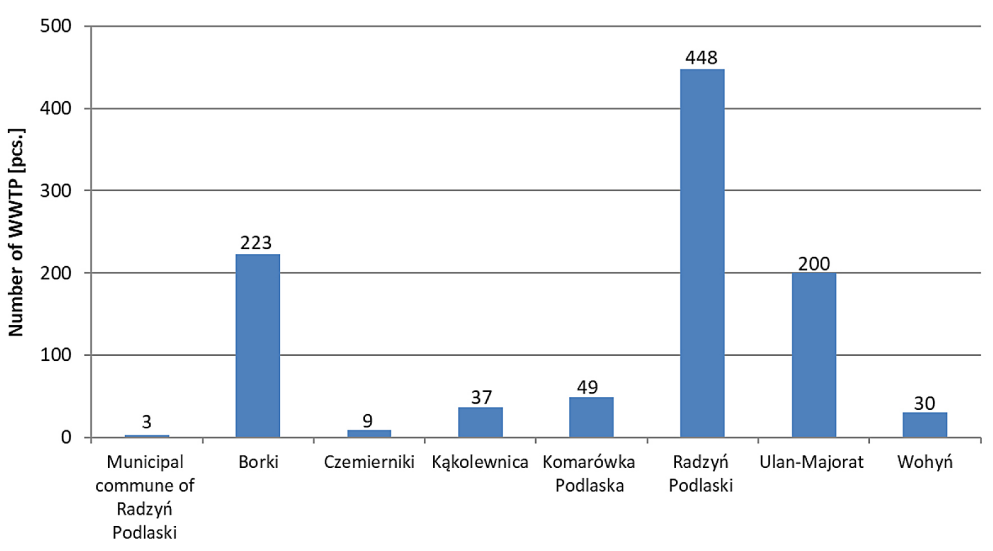

Fig. 5. Number of domestic sewage treatment plants in the communes of Radzyń district in 2016 
operation to relieve users of the obligation to maintain the treatment systems, especially when they are conventional systems which pose many maintenance-related problems that are difficult to handle even by specialists.

Given these observations, particular effort should be put in the promotion and implementation of solutions that bring the greatest ecological benefits, while being cheap and easy to use. These criteria are met, among others, by seminatural systems, such as sand filter systems and constructed wetlands [Jóźwiakowski et al. 2017; Jóźwiakowski et al. 2018; Jucherski et al. 2017; Marzec et al. 2019].

\section{CONCLUSIONS}

1. The water supply infrastructure in the Radzyn district is well developed and supplies water to over $90 \%$ of the inhabitants.

2. The sanitation infrastructure in the district is subservient to the water supply infrastructure, which results in a very large disproportion between the lengths of these two networks, and their coverage.

3. Local governments invest in the expansion of the sanitation infrastructure when they have the necessary financial resources, and investments are made in areas with the highest population concentration, where there is a guarantee of obtaining a high level of economic efficiency of the investment.

4. At the time of the study, there were eight centralized wastewater treatment plants in the district, and most of them had a capacity of up to $400 \mathrm{~m}^{3} / \mathrm{d}$. The largest wastewater treatment plant, located in the town of Radzyń Podlaski, had a capacity of about $3,900 \mathrm{~m}^{3} / \mathrm{d}$.

5. Domestic sewage treatment plants are an important element of the sanitation infrastructure of the Radzyn district - they are used as an alternative to mains networks in areas with a dispersed settlement pattern.

6. The new facilities added to the network of onsite wastewater treatment plants in the Radzyń district are mostly conventional wastewater treatment plants using the low-load activated sludge process or biological filtration beds, and semi-natural treatment plants.

7. The status of the sanitation infrastructure in the Radzyń district, and especially in its rural communes, is unsatisfactory. Public expenditure on the expansion of mains networks should be increased and the disproportion between access to the water supply network and the sewerage network should be evened out. The network of domestic wastewater treatment plants should be expanded taking into account all local conditions, and local authorities should support users in maintaining these facilities.

\section{Acknowledgements}

The publication is funded by the Polish National Agency for Academic Exchange under the International Academic Partnerships Program from the project "Organization ofthe 9th International Scientific and Technical Conference entitled Environmental Engineering, Photogrammetry, Geoinformatics - Modern Technologies and Development Perspectives".

\section{REFERENCES}

1. AKPOŚK. 2017. Update of the National Municipal Wastewater Treatment Program. Państwowe Gospodarstwo Wodne Wody Polskie (in Polish).

2. Błażejewski R., Nawrot T. 2009. How to seal the system for collecting and delivering liquid inaccuracies? Gaz, Woda i Technika Sanitarna, 9, 2-3 (in Polish).

3. Board of the Radzyń District. 2019. Report on the condition of the Radzyń district in 2018 (in Polish).

4. CSO. 2018. Municipal infrastructure in 2017. Warszawa (in Polish).

5. District Office in Radzyń Podlaski. 2015a. Development strategy for the Radzyń district for 2015-2030. Annex 1 to Resolution No. XII/48/2015 of the Radzyń District Council of November 26, 2015 (in Polish).

6. District Office in Radzyń Podlaski. 2015b. Program for the development of the Radzyń district for 2015-2022. Annex 2 to Resolution No. XII / 48/2015 of the Radzyń District Council of November 26, 2015 (in Polish).

7. HeidrichZ.,StańkoM.2008.Directions ofsolutions of wastewater treatment plants for rural settlement units. Infrastruktura i Ekologia Terenów Wiejskich 5/2008, 169-177 (in Polish).

8. http://www.polskawliczbach.pl/powiat_radzynski. access November 21, 2019. 21.20.

9. Jawecki B., Marszałek J., Pawęska K., Sobota M., Malczewska B. 2016. Construction and Operation of Domestic Wastewater Treatment Plant under the Relevant Legislation. Part 1. Infrastruktura i Ekologia Terenów Wiejskich, II/2, 501-516 (in Polish). 
10. Jóźwiakowski K., Steszuk A., Pieńko A., Marzec M., Pytka A., Gizińska M., Sosnowska B., Ozonek J. 2014. Evaluation of the impact of wastewater treatment plants with drainage system on the quality of groundwater in dug and deep wells. Inżynieria Ekologiczna 39, 74-84 (in Polish).

11. Jóźwiakowski K., Bugajski P., Kurek K., Nunes de Carvalho M. F, Araújo Almeida M. A., Siwiec T., Borowski G., Czekała W, Dach J, Gajewska M. 2018. The efficiency and technological reliability of biogenic compounds removal during long-term operation of a one-stage subsurface horizontal flow constructed wetland. Separation and Purification Technology 202, 216-226.

12. Jóźwiakowski K., Bugajski P., Mucha Z., Wójcik W., Jucherski A., Natawny M. Siwiec T., Mazur A., Obroślak R., Gajewska M. 2017. Reliability of pollutions removal processes during long-term operation of one-stage constructed wetland with horizontal flow. Separation and Purification Technology 187, 60-66.

13. Jucherski A., Nastawny M., Walczowski A., Jóźwiakowski K., Gajewska M. 2017. Assessment of the technological reliability of a hybrid constructed wetland for wastewater treatment in a mountain eco-tourist farm in Poland. Water Sci. Technol., No. 75, 2649-2658.

14. Karolinczak B., Miłaszewski R., Sztuk A. 2015. Cost-effectiveness analysis of different technological variants of single-house sewage treatment plants. Rocznik Ochrona Środowiska, 17, 726-746 (in Polish).

15. Kondracki J. 2002. Regional geography of Poland. PWN, Warszawa (in Polish).

16. Marzec M., Jóźwiakowski K. 2007. Operational and environmental problems of the functioning of mini-sewage treatment plants with activated sludge. Polish Journal of Environmental Studies, Vol. 16, No 2A, Part III, 525-529.

17. Marzec M., Jóźwiakowski K. 2010. Efficiency and operational conditions of on site sewage treatment plants with activated sludge. Zeszyty Problemowe Postępów Nauk Rolniczych, 547, 229-236 (in Polish).
18. Marzec M. 2018. Technological reliability of utilization of biogenic pollutants in selected technologies used in small wastewater treatment plants. Przemysł Chemiczny, 97 (5), 753-757 (in Polish).

19. Marzec M., Gizińska-Górna M., Jóźwiakowski K., Pytka-Woszczyło A., Kowalczyk-Juśko A., Gajewska M. 2019. The efficiency and reliability of pollutant removal in a hybrid constructed wetland with giant miscanthus and Jerusalem artichoke in Poland. Ecological Engineering, 127, 23-35.

20. Micek A., Marzec M., Jóźwiakowska K., Pochwatka P. 2018. The condition of sanitary infrastructure in the Parczew district and the need for its development. Journal of Ecological Engineering, 19 (5), 107-115.

21. Mucha Z., Mikosz J. 2009. Rational use of small wastewater treatment plants taking into account the sustainability criteria. Czas. Techn. Środowisko 106 (2), 91-100 (in Polish).

22. Nowak R. 2012. Sewage holding tanks system - potential and real threat to the natural environment. Gaz, Woda i Technika Sanitarna, 6, 263-265 (in Polish).

23. Pawełek J. 2016. Degree of Development and Functionality of the Water Supply and Sewage Systems in Rural Poland. Barometr Regionalny, 14 (1), 141-149.

24. Pawełek J., Bugajski P. 2017. The development of household wastewater treatment plants in Poland - advantages and disadvantages. Acta Scientiarum Polonorum, Formatio Circumiectus, 16 (2), 3-14.

25. Polish Norm PN-EN 12566-3:2016-10. 2016. Small wastewater treatment plants for a population calculation (OLM) up to 50-Part 3: Container and / or home sewage treatment plants on site (in Polish).

26. Statistical Office in Lublin. 2017a. Statistical Vademecum of the Local Government. Radzyń District - A statistical portrait of the territory. Lublin (in Polish).

27. Statistical Office in Lublin. 2017b. Water supply and sewage management in the Lubelskie Voivodeship in 2016. Latest statistical news. Lublin (in Polish).

28. Statistical Office in Lublin. 2018. Statistical Vademecum of the Local Government (in Polish). 